\title{
MUSLIM UMMAH: REALITY OR ILLUSION
}

\author{
* Nawab Sher, Research Scholar, Department of International Relations, Federal Urdu \\ University, Karachi - Pakistan (nawabsher80@gmail.com)
}

\begin{abstract}
United Muslim Ummah was a splendid idea given by Islam to restore the lethargic sections of society and combine the assets into an incorporated, reduced frame. Such a unified movement was important not just to assimilate political and national associations on a solitary stage yet, in addition, to liberate the people from conferred self-interests and narrow observations. The idea was inspiring especially at a time when Arab society was segregated by tribal rivalries, domestic feuds and inter-regional assaults. By eliminating aggressive and exploitative tendencies, this kind of communal harmony produced a cohesive, creative principle for a successful strategy. This was a correct diagnosis made for the difficulties afflicting the ligaments of a diseased society. The aim of the paper is to determine whether present Islamic world can be united under the single banner of Muslim Ummah and recommend measures to enhance unity and sense of brotherhood among the Muslim states.
\end{abstract}

KEYWORDS: Ummah, Muslim, Muslim World, Technology, Unity

\section{INTRODUCTION}

Islam not just gave the possibility of an Ummah in light of honorable ideas yet, in addition, raised the status of the people, regardless of their cast, color, and beliefs. In the meantime, it reestablished the poise of whole humankind and prepared for an indispensable type of presence for every single person. The concept was so beautiful that just by a stroke of its practical implementation all the animosities, hatreds and rivalries were drowned in the stream of peace and cordiality. Based on the principle of brotherhood, equality and justice the society had been liberated from the bonds of slavery and superstition, exploitation and degradation. An Islamic society was a healthy combination of religious injunctions, socioeconomic reforms and administrative measures. This was the society, which the Quran commended as "the best community established for men". (Hamidullah, 1994) 


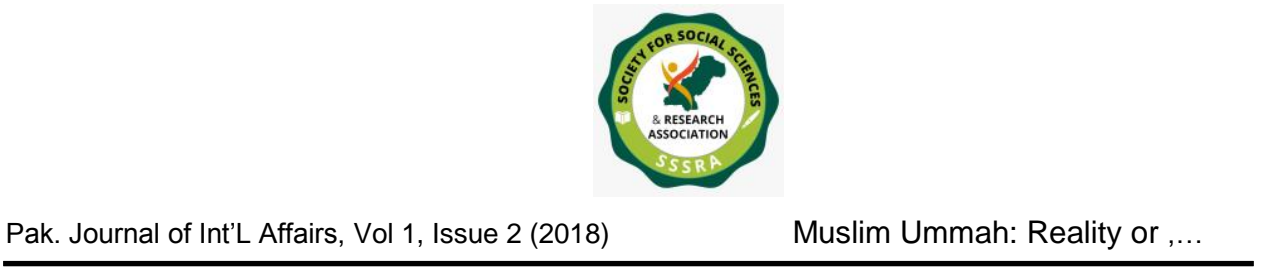

The distinction that Islam established was that of moral excellence and piety. All other grounds were baseless and irrelevant. The Holy Prophet (PBUH), on the occasion of the last Pilgrimage, declared that $\mathrm{O}$ you people, be careful, your God is one. No Arab has a supremacy over a non-Arab and non-Arab is not brilliant on an Arab and no white has dominion over a dark and not a dark over a white except that based on taqwa (devotion). (Asad, 1980) The most important of you in seeing Allah is the person who is the most devoted and exemplary of you. As against any other system of life, which depends on material values only, Islam comprehends life fully and deals with it as a whole; it does not compartmentalize its concepts and is against a double set of principles and values for the various activities of life and for various people and countries. (The Muslim World and the future Economic Order 1979) It has unified vision to look at the various spheres of human activity, the political and economic and the moral; in fact, each and every aspect of life comes under its flood lights.

\section{MUSLIM UMMAH - THE CONCEPT AND HISTORY}

\section{ISLAMIC CONCEPT OF UNITY}

The unity of Allah what's more, pride of man were the basic establishments on which the Islamic state in Medina was set up. The idea of Islamic culture conceived as a unifying force was the underlying idea conforming to the needs of an evolving society. Mr. Draper says in one of his lectures, "The Ummah as conceived and made by the rules under the guidelines of the Holy Prophet (PBUH) had turned into a perfect society brimming with ideas and qualities for a fair, just and empathetic order. Islamic culture was not an egocentric entity; it composed of amiable and peace loving individuals who were devoted to their cause and dedicated to the purpose of life". (Anka 2010)

The Canadian Orientalist, Wilfred Smith, said, "The community (Ummah)) occupies an important position in Islam. It is notable that Muslim society has a significant harmony, that the dedication and union of its individuals are serious, many have perceived that the group isn't a religious body, however a social gathering. The community depends on, as it is incorporated as well, singular confidence. Not exclusively is Muslim 
society held together by basic loyalties and customs, and by a precisely worked out arrangement of qualities and convictions. It throbs with the essentialness of a conviction that is warm and important for the individual member. (Hart, 1993)

\section{HISTORICAL PERSPECTIVE}

By studying history, we can understand that rise and fall of empires is not random, nor does Allah destine the fate of nations. In fact, it is actions of nations that cause their downfall. This is why Allah reminds us of the history of past nations throughout the Quran, so we can learn from their stories.

\section{THE CALIPHATE}

The first caliph was Abu Bakr (RA) after the death of the dear Prophet Muhammad (PBUH). In the brief span of twenty-seven months, he strengthened and consolidated his community and the state, and secured Muslims against the hazards which had debilitated their reality. Hazrat Abu Bakr's (RA) caliphate prospered by Hazrat Umar (RA). In the era of Hazrat Umar (RA) Islam was widespread broadly in the east and west of the Egypt, Syria and Persian Empire. He was the author of the main open treasury and a complex money related administration. After the demise of Hazrat Umar (RA), Hazrat Usman (RA) was chosen as the following caliph. Hazrat Usman's (RA) territory extended to the west of morocco, east of Afghanistan and to the north of Azerbaijan and Armenia. During his caliphate naval force was composed, regulatory divisions of the state were changed, and numerous open tasks were extended and finished. After Hazrat Usman's (RA) martyrdom, the office of the caliphate was handed over to Hazrat Ali (RU). Hazrat Usman's (RA) murder was the reason of the civil strike on an enormous scale. Hazrat Muawiya declined to obey Hazrat Ali (RU) until Hazart Usman's blood was avenged. Finally, Hazrat Ali (RU) agree with the de-facto government of Hazrat Muawiya in Syria. Despite the fact that the time of Hazrat Ali's (RU) caliphate was defaced by the civilian strike, he, in any case, presented various changes, especially in the exacting and gathering of incomes. (Galadanchi, 2001)

\section{UMAYYAD}


After Hazrat Ali (RU), Hazrat Muawiya presumes the caliphate and from that point, the caliphate was inherited, going starting with one ruler then onto the next. The Umayyad caliphs progressively changed the unique region vanquished by Muslim armed forces into a united Empire, with a typical belief system. Throughout that period, the rule of the Muslim world was extended as of West of China to the South of France and Damascus turned into the capital. In the tenure of the Islamic victory the areas were also extended from Transoxiana in the East, Central Asia and France to the Sindh and North Africa to Spain, yet in addition, these fundamental, communal \& lawful organizations of this recently established Muslim biosphere were built up. (Khalid, 2000)

\section{ABBASIDS ERA}

The Umayyad was defeated by the Abbasids and the capital was change from Damascus to Baghdad, which was soon turned into a learning and cultural focus and in addition it will be a political heart into the whole world. The Abbasids tenure was round about for 500 years. Their energy progressively wound down and unmistakably Islam could never again work adequately as a solitary political unit. The breakaway caliphate of the Ismaili ruled Egypt, Fatimid's ruled quite a bit of Arabia, Palestine, North Africa and Syria. Turkish armed force officers gain control in Iraq, Iran and central Asia and built up free states. The Abbasid caliphate was finally abolished when Hulaku Khan captured Baghdad in 1258 AD. On one hand we see great tides made in sciences, arts, welfare and administration culminating in creating most advanced society of the time but on the other hand we also see forces of disruption in Muslim society. The golden age of Islam begun when one of the Umayyad princes founded Umayyad rule in Spain. Cordoba was turned into the capital to be very soon the city was counted in the most spectacular city in European population. Muslim power kept on winding down until the point that the last Muslim line was crushed in 1492 AD in this way bringing almost eight centuries of Islamic power to an end in Spain. (Maiwada, 1999) 
The Mongols, who destroyed the eastern base of Islam and ruled for a century from the Sinai desert to India, soon changed to Islam. They ruled with Taimur and his relatives, who made Samarcanda the capital and ruled from 1369 to 1500.

\section{OTTOMAN EMPIRE}

On the other hand, the Turks have grown throughout the Anatolia and also in some regions of Europe. They reached their peak of domination when their forces arrived in Hungary and Austria. From the seventeenth century with the rise of the powers of Western Europe, the energy of the Ottomans began to disappear and, finally, the six centuries of Ottoman rule after the First World War were abolished by Kamal Atatürk in 1924. (Galadanchi, 2001)

\section{PERSIA}

Toward the east in Persia, another empire call the Safavids came to control in 1502 AD. Their capital, Isfahan, ended up plainly a standout amongst the most delightful urban communities. The Afghan attack of 1736 AD put a conclusion to Safavid lead and arranged the autonomy of Afghanistan in the nineteenth century.

\section{INDIA}

As for India, Muslims step by step increased political power starting in the mid-thirteenth century. In any case, that time which denoted the extension of Islamic culture as well as Islamic world, it ended with the success of Babur in India in 1526. He established the powerful Mogul empire which lasted until his empire was abolished by the British in 1857 . (Hamidullah, 1994)

\section{MALAYSIA AND INDONESIA}

Islam began to spread in the north of Sumatra in the 12th century and the Muslim kingdoms were soon built in the continental mass of Malaysia, Sumatra and Java. Islam started to spread throughout the Malay world, including Malaysia, Indonesia, the southern Thailand and southern Philippines. 


\section{AFRICA}

Islam arrived in the East Africa at the starting of Islamic era. By the 14th century, Muslim sultanates were established in Harare in East Africa, Mali and Timbuktu in West Africa.

\section{REASONS FOR DECADENCE}

The problem began blending among the power contestants not long after the demise of the Holy Prophet, coming about into the warring camps, uprisings in the distant territories, decrease of focal specialist and the prevalence of the divergent over the centripetal powers. Also, the nonattendance of the law of political progression was the foremost reason for the insecurity and decay of the Muslim run the show. Besides, the topic of authenticity, which has tormented the Muslim world from the earliest starting point, stays unsolved. Under these compulsions, force remained the ultimate arbiter. This continues to be the case till today throughout the Islamic world. (Maiwada, 1999)

Deviations from Islamic fundamentals were permitted to occur, the most important of them the separation between faith and political conduct. Sects and innovations destroyed the uniqueness of true Islam. The decline of ilm and fikr spread throughout Islamic world and they were reluctant to take over the new sciences and skills, even those affecting the art of warfare.

\section{PRESENT ISLAMIC WORLD AND THE EMERGING CHALLENGES}

\section{MUSLIM WORLD AFTER WW-II}

In the period when the expansion of the European colonies was high in the 19th century, most of the Islamic world was under just a very few European specialist. After the First World War with the division of the Ottoman empire, several states were granted autonomy and others became another substance, then the others became the French provinces. The European forces have carved the Islamic imperial state in 54 smaller states. The colonial powers ensured that a structure was created in which these nation states and their governing bodies were concerned regardless 


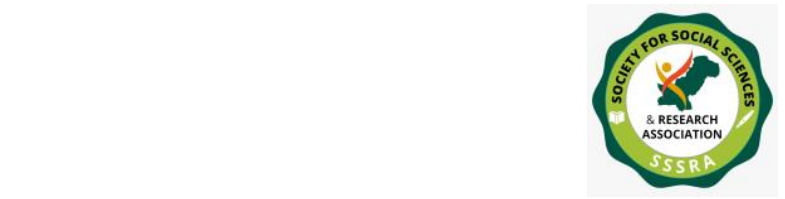

Pak. Journal of Int'L Affairs, Vol 1, Issue 2 (2018)

Muslim Ummah: Reality or ,..

of their national interests. (The Muslim World and the future Economic Order 1979)

\section{POLITICAL FIELD}

The main gap in the Islamic world was the political turbulence left by the control of the pioneers who supported the Muslims in the struggle for their strength and political authenticity. Political progressivism, similar to religious radicalism, has been crushed and relatively neglected. Professor Vambery concluded: It isn't Islam and its principle that has crushed and understood the current situation in the Muslim world, but the suppression of the Muslim pioneers who have deliberately degraded and maintained the teachings of the Prophet (peace be upon of Him), the beginning of a Muslim renaissance. Under the weight of the West, some nations have made some progress in the implementation of an electoral system, while most of the Muslim nations have autocracy in a context or in another. Political precariousness is exacerbated by the marginal problem abandoned by the pioneering authorities. (Anka 2010)

\section{ECONOMIC FIELD}

Many economic problems were left behind the colonial system which have undermining impact on the Muslim world. Moreover, many Muslim countries which were occupied were ignored by the occupying powers in the field of development like education and health management. This fresh world of science and technology has evolved a gigantic and powerful economic system with an all-pervading, all embracing monetary structure from whose shackles none can escape. Today the entire Muslim world is subservient to the West's economic system and monetary structure. The oil producing countries find their entire oil revenues recycled into the Western world through innumerable devices, while the non-oil producing Muslim countries are heavily indebted to the Western world, having to pay $1 / 3^{\text {rd }}$ to $1 / 2$ of their foreign exchange earnings annually in debt servicing. (Adnan, 2013)

\section{BREAKDOWN OF SOCIAL COHESION}

After gaining independence from colonial powers, the Muslim societies were supposed to have become stronger and more cohesive. It was clear that tribal and rural groups could no longer provide asabiyya (the 
Islamic roots of loyalty and cohesiveness of the group). The outcome is a loss of energy and attachment and Muslims wherever are voicing their alert at the collapse of the civilization.

\section{THE EXPORT OF WESTERN VALUES}

The colonial period of foreign dominance brought cultural humiliation and distortion. New European elite despite its strong nationalist impulses was culturally alienated from its past and imposed its own elitist, quasi-Europeanized culture upon the people. Actually, these societies and cultures were deprived of the opportunity to develop naturally and organically. Rather, they were forced into new mold in ways that did instant violence to the old practices and denied opportunity to gradual adaptation. They were pushed by the colonial masters into instant Cultural Revolution. This created social and cultural bifurcation, loss of cultural tradition that continues to extract social costs even today. (Khalid, 2000)

\section{THE STATE OF EDUCATION}

The nineteenth and twentieth centuries saw torrential flows of creative change in Western nations. The ten-year period from the discovery in 1895 of radium to the idea of comparability in 1905 determines an important change in the way of thinking and occupation of science and, therefore, advanced developments and advanced devices in the field of consistent revelations, it is interesting note that Muslims who are rich in oil and gas resources cannot design and build a machine that allows them to reach the coherent resources they have access to. Not even a single Muslim state can pretend to be a mechanical nation. In today's world, education is the road to innovation and innovation is the road to monetary improvement. It is one of the components of financial change. (Hamidullah, 1994)

\section{THE CLASH OF CIVILIZATIONS}

With the fall of communism, a general perception has started to frame in the West that the Islam would be the new enemy of the world. The thought solidified on September 11, when Bush proclaimed war against Islam. The Italian Prime Minister, Berlusconi proclaimed freely that the major enemy of the western civilization is Islam. The veiled 
problem for the West is not Islamic fundamentalism. It is Islam, another human development whose people are convinced of the transcendence of their lifestyle and focus on discrete energy. The US was not the issue for Islam; it is the West. They have distinctive human civilizations and individuals are persuaded of the comprehensiveness of their way of life and trust that their predominant if deteriorating, imposes power on them the commitment to broaden that culture all through the World. (Huntington, 1993)

It is obvious that the wars of the 21 st century will not be fought with weapons. They will be more an exploration of belief systems and social values. The real rivalry would be in the place known to two societies and developments, one in terms of Islamic values and another in estimates of realism, patriotism and liberalism, both monetary and political. An evaluation of the basic materials shows that the opponents of Islam are now facing the method of social and good subversion in the Muslim world through different methods of psychological warfare. (The Muslim World and the future Economic Order 1979)

\section{DEMOCRACY}

The West has always supported despots, dictators and tyrants as it was always easier to manage and manipulate few at the top, rather than deal with a huge mass of people. ${ }^{24}$ Today the process continues uninterrupted with totalitarian regimes, Kingships and sheikhdoms in the Muslim world, well supported by West. These are insecure regimes, more scared of their own people than the foreign powers. In countries, where Muslims do make an effort and try to bring a true representative government, the process is sabotaged by the west. Western pioneers realize that popularity based procedures in Western nations frequently make governments antagonistic toward the West; both try to impact the races and lose their eagerness for the advancement of majority rules systems in these social orders.

\section{THREAT OF IMPERIALISM}

Proceeding with its approach, the West will keep on trying to protect its pre-prominent position and shield its interests by characterizing these interests as interests of the "world group". The term gives worldwide authenticity to activities that mirror the interests of Western forces. The 
West is keen on coordinating the economies of non-Western social orders into the worldwide monetary frameworks it controls. (Huntington, 1993) The West advances its financial advantages through the IMF and other global foundations and forces this approach on different countries it regards proper. Bad faith is the cost of dominion. These forces advance majority rules system, however not on the off chance that they convey Islamic fundamentalism to control; Non-expansion is booked for Iran and Iraq, yet not for Israel; Free exchange is the principle hub of financial development, yet not for agribusiness; Aggression against oil proprietorship Kuwaitis are enormously spurned, yet not against Bosnians who don't have oil. Muslim world today is a dependent world, a captive world with little maneuverability, deprived of initiative and bereft of power to take and implement decisions beneficial for them. (Galadanchi, 2001)

\section{DEPENDENCE ON THE WEST}

The most distressing aspect of today's structure is that the countries having raw material do not have any control over the prices of their own products, which are determined by a few international associations belonging to the group of industrialist countries. Invariably, raw material prices are kept low, while the prices of finished goods manufactured by the advanced industrial countries are pitched high. This disequilibrium has broken the back of Muslim countries making them hewers of wood and drawers of water. As for the military strength of the Muslim countries, every one of them depends for its military hardware entirely on the Western World with little of its own production capability. If West stops the flow of arms, the entire war machine of a Muslim country will come to a grinding halt. Today world of science, technology and expanding frontiers of knowledge is yielding more secrets of nature, enabling humanity to employ them for improvement and progress. Muslims have hardly any share in this diversified and dynamic world of power. Their finances as well as foreign affairs are controlled by the Western powers through puppet governments using Muslim intelligentsia and their masses act as mute spectators of the drama. The Muslim's economic outlook is unhappy; its scientific progress dismal, the military strength leaving much to be desired, its moral fiber weak. It is all because of this bleak background that none of the freedom movements that developed in various Muslim countries could assert themselves for long. They could not withstand Western economic and cultural domination. 
Kamal Ataturk's war of independence was a brilliant performance defeating British designs but later this brave nation became dependent on West culturally, economically and politically. (Nairruti, 2012)

\section{ROAD TO DESTINY - THE UNITY}

\section{UMMAH - REALITY OR ILLUSION}

It is fascinating to take note of that on account of all the European realms of the nineteenth and twentieth millenniums, a type of political solidarity rose on totally extraordinary societies and ethnic gatherings. This was to a great extent accomplished through the presentation of a typical dialect and training framework, it was conceivable to make a domain with a specific level of social association, yet considerably more critical was an expansive market for business relations.

In any case, when we look at the gigantic potential that Muslim nations have, given their normal chronicled foundation, yet we watch the absence of regular essential accomplishments somewhere else. The troublesome inquiry emerges, for what reason not the Muslims? Then again, it is conceivable to contrast the OIC and more aggressive models of present day Europe. The last have prevailing with regards to shaping a unit of financial, political and resistance systems in a way that ought to draw in every one of the individuals who can do as such. (Hart, 1993)

On account of Europe, there was no recorded solidarity to be glad for; Indeed, for quite a long time Europeans have battled for patriotism, religion, riches and outskirts, yet have possessed the capacity to locate their regular social roots. In view of these regular roots, following a sensible methodology starting with one stage then onto the next, they at long last accomplished something. Most importantly, Europe has tried the possibility of a typical market; has been fruitful and has prompted the potential outcomes of an European Parliament, and so on. They understood that European predetermination lies in their capacity to stay joined together28. What amount would Muslims be able to gain from this experience? For what reason cannot the O.I.C be like a type of political solidarity or possibly to a typical market? With respect to the destinations of the OIC, it is found that these don't go past participation and coordination; Unity isn't planned as an achievable objective. (Asad, 1980), 
Making a political or financial solidarity requires eagerness and a great deal of readiness. The way that the world is aggressive and that numerous universal forces would prefer not to see new power cannot be overlooked. In this manner, it is critical to talk about the recommendations for a typical Muslim market and the Smart Association. This is the main measure accessible to Muslims today even with globalization. In their suggestions for the change and rebuilding of the OIC, the famous Persons underlined the earnest need to rebuild, change and rejuvenate the OIC, incorporating the important changes in the OIC Charter. Be that as it may, it stays to be seen whether the board suggestion will be actualized or on the off chance that it will end up being a dialog discussion. (Para, 2014)

\section{WAY FORWARD.}

In the ensuing international politics, it is evident that Islam is the major challenge to the West. The changed adjust of energy among civilizations makes it progressively troublesome for the West to accomplish its objective on a few imperative issues, for example, the multiplication of weapons, human rights and movement, et cetera. To limit its misfortunes, the circumstance requires that the West demonstrations skillfully and its financial assets are the main thrust to manage different organizations, to fortify its solidarity and facilitate its approaches, to make it troublesome for different social orders, a nation Western play against another and advance and endeavor the contrasts between non-Western countries. (Khalid, 2000)

Under this present international environment, OIC should assume a more active role in bringing about a closer political integration among the Muslim states. Numerous political options have been analyzed by Muslim scholars who are working for integration of Muslim Ummah. The salient features of their discourse include the following:

(a) The acknowledgement of the sovereignty of Allah in Islamic States.

(b) The application of the Divine law - Shariah. 


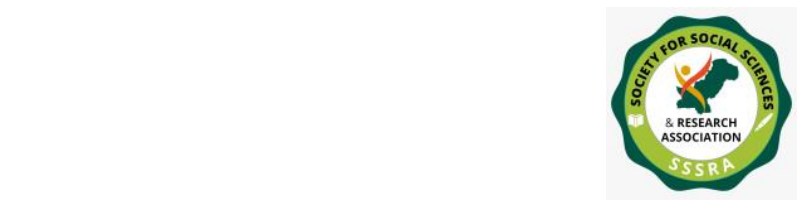

Pak. Journal of Int'L Affairs, Vol 1, Issue 2 (2018)

Muslim Ummah: Reality or ,...

(c) Arbitration of fratricidal international disputes in light of Shariah.

(d) Gradual integration of Muslim states by forming regional associations initially.

Meanwhile, it appears to be improbable that the caliphate structure of rule would be reestablished later on. At any rate, Muslims must be gone through an European model of the association of autonomous states, including common ones, which depend on the asset of social solidarity, however bit by bit work towards political and financial solidarity. (Anka 2010)

The test of globalization leaves no contrasting option to Muslims, with the exception of that they confront a canny affiliation. The OIC can assume an imperative part in the creation and advancement of such affiliations, giving the system in which specialists can meet up to create future arrangements and techniques. The European recreation is unquestionably an exceptional case of political will. The way that the individuals who viewed themselves as genetic adversaries prevailing with regards to establishing financial gatherings and advancing towards a dynamic political association. Such a procedure is confirmation, to the point that history isn't foreordained and legislative issues remains the key factor. (Shahabuddin, 2014)

In view of numerous hurdles, revival of the Muslims is characteristically diverse. Some options have been highlighted below but they are highly broad based and details can be worked out. The broad outline plan is divided into following options:
(a) Political Reorganization
(b) Economic Integration
(c) Education
(d) Unity on Fiqh

\section{POLITICAL REORGANIZATION}

The prevailing global trend encouraged international deescalation. New vistas are being opened for greater understanding amongst nations. The merger of the two Germanys and subsequent merger of 
Europe is a pointer in this regard. Hence global trends encourage political rapprochement in the Muslim World also.

Scholars have proposed a number of political options which prescribe organizational, confederal or federal framework irrespective of the system adopted. The state apparatus must be efficient and reconcile the present day technological advances with the eternal Islamic values. OIC is a milestone in the first approach. On the other hand, industrialized countries are far ahead of the Muslim world. Western Europe is quickly moving towards a confederal framework, whereas USA is a living example of the federation.

\section{ECONOMIC INTEGRATION}

Currently, all integration process commences from economic cooperation. The economic integration of states results from a wide host of factors. The European Economic Community is largely born out of the necessity of curbing over production while encouraging healthy competition and cooperation. The economy predicament of Muslims is aggravated by the fact that what was lost by the colonial powers in terms of political power has been expanded in the form of trade relations and is visible in the form of economic clout. There is an urgent need for greater cooperation in economy so that the member states can play an effective role in the international economic scene. The exports of Islamic world are in primarily raw commodities which are then subsequently processed in the industrialized countries. (Usmani, 1998)

Islamic countries must initiate a program of technological exchange and share the fruits of their research with other Muslim countries. Some countries have specialized in certain industries. An integrated technological framework will greatly assist in accelerated development of the Islamic World. This technological exchange must include exchange of technical experts and skilled labor's. (Adnan, 2013)

The international monetary system does not favor the Islamic countries. Cash liquidity may be transferred to developing Muslim countries which have necessary infrastructure to run the venture successfully. It is by developing a strong economic base that the Muslim countries would be able to get rid of foreign hegemony. (Usmani, 1998) 


\section{EDUCATION}

Education is the most potent challenge which the Muslims face today. It is challenge both in terms of quantity and quality. Even a cursory comparison of about a billion people living in fifty-four Muslim states with the non-Muslim population of the world presents an alarming situation. It reveals the lowest literacy rate for the Muslim community. (Kumar, 2013)

The examination of the particular upset in human undertakings after the entry of Islam is significant that the inspiring power was not political or monetary, but rather basically educational. Then again, today the Muslim world is denied of its identity and its spirit and is absolutely subject to the Western world for its reality. Therefore, the warmonger and radical outlines of the West have damaged different countries through pioneer fear. The Western culture that portrays independence is the way to the "wellspring of all issues". Just the West chooses: "When satellites are utilized to teach Muslims or dispatch bombs, to dispose of their grip, Islam must build up its designers and researchers, assemble its own particular weapon and avoid military reliance. (Masomi, 2014)

Therefore, Muslims have to devise its educational policy to provide an opportunity to every individual to seek knowledge and acquire education. Universal education has to be aim of every Muslim country. Besides, ethical and cultural training must form a part of the educational program tied up with the charter of Quran. The fact is that Islam does not distinguish between secular and religious education that has been the hallmark of the great days of Islam. (Rao 2013)

\section{UNITY ON FIQH}

All the important sects of Islam have its own system of Fiqh, the sub-sects have their own dogmas, which are accommodated in the sectarian beliefs and there is a continuous competition among them. Because of which for the most of the Muslims their sect comes first and Islam afterwards. There are external forces which air this divide between the Muslims. In order to come out of these dogmas, cohesion and unity between various sects has to be preferred at the expense of their inner loyalties to a particular sect or sub-sect. 


\section{CONCLUSION}

After having discussed a number of problems facing Muslim states, the real question is to what extent Islamic countries can achieve a new degree of solidarity amongst them especially when all the western forces would not wish such cohesiveness? History shows that solidarity can be enhanced by negative or positive stimuli. The solidarity among Muslim states has generally been enhanced by negative factors especially against common enemies. Nevertheless, positive factors to pursue common values could play a crucial role in uniting Muslims in long term. Muslims speak of common values but have failed to develop a clear cut, concrete body of positive programs and approaches that most Muslim states can agree on.

The Islamic ecosphere contains a tremendous decent variety of people groups and societies with altogether different verifiable encounters. Genuine contradictions between the principle ethnic gatherings can cause doubt or struggle. These ethnic divisions depending upon the issue often weigh more heavily than the unifying aspects of Islamic culture. Rivalries exist even within the shared culture of Arab states themselves, often based on geopolitical competition. Modern Arab states continue to jockey for position against each other. The Arab world is far from united politically regardless of how critical these issues may be for the region. Similarly, sub national ethnic differences within the existing multinational and multi sectarian states have a deep and divisive history.

Additionally, religion too, divides Muslims in Shias and Sunnis; among different Shia and Sunni sects- all represent fracture lines in the society. Historically, outsiders including western governments have exploited and even magnified these differences, for the purpose of subjugation and geopolitical advantage. Yet these differences and dissensions do not go away by ignoring their existence. The divide between haves and have-nots in the Muslim world is another significant fault line that tends to hinder co-operation. The oil wealth has also served to preserve traditional ruling structures such as monarchy. Even the political style and international orientation of the oil state differs from the non-oil states.

Muslim nations at present have slight in mutual in footings of security matters. Each state's national security policy remains a source of divisiveness. As long as the region is hostage to unpredictable ideological states, no natural and sustained cooperation among Muslim states can be 
expected, especially on security issues. In sum, differences in character, outlook, economy, and geopolitics tend to differentiate the Muslim states. It is natural that such a diversity of states, structures, peoples, culture and geography would create differing outlooks on the world and the conduct of foreign relations. Another important question arises that how strong would be the force of shared Islamic culture once compared against others national interests? In the real world, although Islamic solidarity is an attractive ideal but the world is too complicated for that. Relationship between the states is based on a wide variety of interests and preferences, shifting over time, rather than on a single ideological principle. Additionally, it is obvious that under the circumstances of marked friction between Muslim and Western states that Muslim solidarity could not be perceived as positive in the West.

Despite the fact that present state of Muslim states is far from unity as a single Ummah, Muslims should not be discouraged. The West emerged successfully out of the Dark Ages despite Church's authoritarian and negative attitude to life is a living example for them. Later West build a great civilization whose roots lie embedded in Greco-Roman heritage. Additionally, West considered religion a hurdle in the way to progress and so separated the Church and the state. On the other hand, this course is in sharp contrast with the Islamic position and Muslims may take advantage of their religion to work together to achieve the cultural height and the respect they dream of. The Quran has guaranteed them that the society which surrenders to the will of Allah cannot fall flat. History of Muslim has indicated it over and over. At the point when incident happened, the most dedicated Muslims depended on religion, and the Muslim Ummah resuscitated, as well as for the most part has been more fruitful. ${ }^{39}$ In spite of all the problems which the Muslims suffer, the religion (Islam) is the binding force amongst them and with other similarities in values could be exploited as a uniting block for the Ummah.

\section{RECOMMENDATIONS}

After having discussed the problem of Muslim Ummah and them inter and intra state difficulties, it is prudent now to discuss the viability/non-viability of the ways and means to the formation of Muslims into Muslim Ummah. Before proceeding any further, it is important to define the exact nature in which Muslim states can be united. 
A modern federation of Muslim state under the western concepts of federation as an old time Caliphate or a modern confederation of Muslim States. Should all the Muslim states of the World quickly get together and merge themselves and declare a union of Muslim states administered by a supranational government? This may appear to be most idealistic goal for Muslims but practically speaking it may become difficult preposition under the prevailing times. Judging the Muslims from their past, it may appear logical that Muslims may unite under the banner of Caliphate. If it is to be born out of a union of independent Muslim states, the question arises what precisely would be the form in which it should be accomplished in future, as all the Caliphates throughout the history has varied in form and substance from the characteristics of present day Muslim states. Additionally, the banner of Caliphate already had been rendered obsolete by the march of history.

As above two options are not practicable, this leaves us to consider the only viable option for the unification of Muslim states in "Confederation of Muslim States". The idea of confederation fits in well with the current norms of the unions of states, which are bringing the world closer through free markets reforms and other bilateral considerations for a regional unification of states. For the Muslim nations the idea of confederation reconciles well with their status as independent sovereign states of the world at the same time it strengths them both individually and collectively in fields of economics, trade, finance and defense.

It works parallel to other unions of independent states such as EU on common grounds is unlikely to create any threat or controversy as the idea of a federation. Only increased mutual trust, which can come only from more transparent, moderate, predictable, and democratic governance, can lead to more confident cooperation among Muslim states. If the Muslim world seeks greater unity and commonness of purpose, it would need to attend to these urgent internal problems.

\section{ASSOCIATION OF ZONAL FEDERATIONS}

The economic challenges facing Muslims after 9/11 could be successfully confronted with association of zonal federations in which geographically contiguous, culturally and linguistically homogenous areas within the Ummah could explore the avenues of economic co-operation. Though Islamic countries have developed organizations like ECO, the 
Persian Gulf Co-operation Council and D-8 etc. but are limited to a specific group of countries and Muslims need to develop such organizations on the regional basis. This development of monetary and exchange collaboration inside provincial groupings would be a critical factor in fortifying fellowship and solidarity among Muslim nations. This could be accomplished through scholarly, profound and look into based joint effort and afterward make the fitting reason for seeking after and actualizing shared intrigue goals. Besides, a huge system of organization data could elucidate the shared needs and capacities of Islamic nations. In the meantime, money related and fiscal arrangement and the coordination of exchange duties between Islamic nations can be additionally created to encourage exchange relations. This could be proficient through various activity gatherings to think about business structures, internet business, blend business banks, distinguish related advantages, advance neighborhood training and receive a typical worldwide position.

Muslim states of Middle East, Central Asia and Southeast Asia can effectively co-operate to meet its own energy requirements by developing the requisite power, oil and gas pipe lines. The infrastructure could be further developed to export these resources to the world market. Similarly, the Muslim states rich in other mineral resources can provide a sound industrial base for a common market.

\section{PSYCHOLOGICAL INTEGRATION}

The psychological integration may be promoted by cultivating a broad complex of positive toleration for cultural differences as described by Werner Levi" cultural diversity within social unity". Similarly, with the development of the inter-governmental and private agencies for the purpose of promoting intellectual co-operation among the Muslim states, a greater social understanding and awakening can result from mutual contacts. It means that the national association of the lawyers, journalists, laborers, employers, engineers, scholars, businessman etc may gradually be developed into Islamic World Associations. 


\section{REFERENCES}

Adnan, A. A., (2013) Bank Choice behavior among Malaysian Muslims: A qualitative approach, Research Journal of Social Sciences, 3(2), 1-8,

Anka L.M., (2010) Prophet Muhammad (SAW) our supreme Leaders and Role Model the Pakistan Futuristic Foundations and Institute, Islamabad, Pakistan, pp-25-26

Asad, M., (Dr.) (1980), The Message of the Qur'an, Gibraltar: Dar alAndalus,

Galadanchi B.S. (2001) Islamisation of Knowledge: A Research Guide, the International Institute of Islamic Thought, Nigeria Office, pp-20-21

Hamidullah, M., (1994) Introduction to Islam, DarulIshaat, Karachi, Pakistan, pp-112-113

Hart, M. (1993) The 100 A ranking of the most influential persons in history, Carol Publishing group inc. London, p-45

Huntington, S. P.,(1993) The Clash of Civilizations, Foreign Affairs, pp22-49.

Khalid I.D. (2000) Islamisation of Knowledge: A Methodology Occasional papers, International Institute of Islamic Thought, Herndon Virginia, London, 11-12

Kumar, I. A., (2013) Teacher Education in the age of Globalization, Research Journal of Educational Sciences, 1(1), 8-12, 
Maiwada, D.A., (1999) Islamisation of Knowledge: Historical Background and Recent Development: Islamisation of Knowledge Series, the International Institute of Islamic Thought, Nigeria Office, pp- 23-25

Masomi, E., (2014) Survey on the role of knowledge management on the quality of working life, case study: Islamic Azad University, Iran, Parsabad Branch, Research Journal of Recent Sciences, 3(2), 100-108,

Nairruti, J., (2012) Women in Afghanistan: Caught in the middle, International Research Journal of Social Sciences, 1(2), 1-7,

Para, R. B., (2014) Technology and Impact on Dalit Education: An empirical analysis, Research Journal of Educational Sciences, 2(1), 13-18,

Rao M.C. (2013) Suggestive Measures for attainting excellence through higher education, Research Journal of Educational Sciences, 1(7), 1-3,

Shahabuddin, S. (Dr) (2014) The role of multimedia super corridor in the cyber development of Malaysia, Research Journal of Social Sciences, 3(4), 33-37,

The Muslim World and the future economic order (1979) Islamic Information Services Limited London, pp-130-131

Usmani, M. T.,(1998) . An Introduction to Islamic Finance, Idaratul Ma'arif, Karachi, Pakistan, pp-238-239 